\title{
Harmonisasi Prinsip Perdagangan Internasional pada GATT dalam Undang- Undang Nomor 7 Tahun 2014 tentang Perdagangan
}

\author{
Yudha Aji Pangestu*;Bernard Sipahutar; Budi Ardianto \\ Fakultas Hukum Universitas Jambi \\ *Coresponding author: yudhapangestu1354@gmail.com
}

$\begin{array}{ll}\text { Submission } & : 26 \text { Agustus } 2020 \\ \text { Revision } & : 03 \text { Maret } 2021 \\ \text { Publication } & : 18 \text { Maret } 2021\end{array}$

\begin{abstract}
The purpose of this research is to find out how the implementation of the principles of international trade of General Agreement on Tariffs and Trade (GATT) and Law Number 7 of 2014 concerning Trade and to find out how the harmonization of the principles of international trade of General Agreement on Tariffs and Trade (GATT) in Law No. 7 of 2014 concerning Trade. This type of research is normative legal research. The results of the research that have been carried out are the implementation of the principles of international trade of General Agreement on Tariffs and Trade (GATT ) and Law Number 7 of 2014 concerning Trade, based on Law Number 7 of 1994 concerning Ratification of the Agreement Establishing The World Trade Organization. World Trade) contains content or material that contains GATT / WTO principle arrangements, namely in letters $A, B$, and $C$, as well as harmonization of the principles of international trade of General Agreement on Tariffs and Trade (GATT) in Law Number 7 of 2014 concerning Trade, that In Law Number 7 of 2014 concerning Trade, there are several legal principles in international trade arrangements. The conclusion of this study is that based on Law Number 7 of 1994 concerning Ratification of the Agreement Establishing The World Trade Organization, there is content or material that contains the principles of GATT / WTO, namely in letters
\end{abstract}


$A, B$, and $C$, as well as harmonization of the principles of international trade of General Agreement on Tariffs and Trade (GATT) in Law Number 7 of 2014 concerning Trade, that in Law Number 7 of 2014 concerning Trade there are several legal principles in regulating international trade.

\title{
Keywords: General Agreement on Tariffs and Trade, International Trade Law.
}

\begin{abstract}
Abstrak
Tujuan penelitian ini adalah untuk mengetahui bagaimanakah implementasi prinsip-prinsip perdagangan internasional pada General Agreement on Tariffs and Trade (GATT) dan Undang Undang Nomor 7 Tahun 2014 Tentang Perdagangan dan untuk mengetahui bagaimanakah harmonisasi prinsip-prinsip perdagangan internasional General Agreement on Tariffs and Trade (GATT) dalam Undang-Undang Nomor 7 Tahun 2014 Tentang Perdagangan. Tipe penelitian ini adalah penelitian hukum normatif. Adapun hasil penelitian yang telah dilakukan adalah implementasi prinsip-prinsip perdagangan internasional General Agreement on Tariffs and Trade (GATT) dan Undang -Undang Nomor 7 Tahun 2014 tentang Perdagangan, berdasarkan Undang - Undang Nomor 7 Tahun 1994 Tentang Pengesahan Agreement Establishing The World Trade Organization (Persetujuan Pembentukan Organisasi Perdagangan Dunia) terdapat isi atau materi yang memuat pengaturan prinsip GATT/WTO, yakni pada huruf A, B, dan C, serta harmonisasi prinsip -prinsip perdagangan internasional General Agreement on Tariffs and Trade (GATT) dalam Undang - Undang Nomor 7 Tahun 2014 Tentang Perdagangan, bahwa dalam Undang - Undang Nomor 7 Tahun 2014 Tentang Perdagangan terdapat beberapa prinsipprinsip hukum dalam pengaturan perdagangan internasional. Kesimpulan penelitian ini adalah berdasarkan Undang-Undang Nomor 7 Tahun 1994 Tentang Pengesahan Agreement Establishing The World Trade Organization (Persetujuan Pembentukan Organisasi Perdagangan Dunia) terdapat isi atau materi yang memuat pengaturan prinsip GATT/WTO, yakni pada huruf A, B , dan C, serta harmonisasi prinsip-prinsip perdagangan internasional General Agreement on Tariffs and Trade (GATT) dalam Undang - Undang Nomor 7 Tahun 2014 Tentang Perdagangan, bahwa dalam Undang - Undang Nomor 7 Tahun 2014 Tentang Perdagangan terdapat beberapa prinsip-prinsip hukum dalam pengaturan perdagangan internasional.
\end{abstract}

\section{Kata Kunci: General Agreement on Tariffs and Trade, Hukum Perdagangan Internasional.}




\section{A. Pendahuluan}

WTO merupakan metamorfosis dari Perjanjian iUmum Bea Masuk dan Perdagangan iatau GATT (General Agreement on Tarrifs and Trade) yang didirikan tahun 1947, sebagai bagian dari kesepakatan di Bretton Woods, Amerika. Sejak 1947 ada tujuh perundingan dagang dimana Putaran Uruguay adalah perundingan paling akhir yang terpanjang (berlangsung dari September 1986 hingga April 1994), rumit dan penuh kontroversi sebelum melahirkan WT0. ${ }^{1}$ Organisasi ini memiliki kedudukan yang unik karena organisasi ini berdiri sendiri dan terlepas dari badan kekhususan PBB. Pembentukan WTO ini merupakan realisasi dari cita-cita lama negara-negara pada waktu merundingkan GATT pertama kali (1948). ${ }^{2}$

Dewasa ini kegiatan negara di bidang perdagangan internasional diatur sekumpulan peraturan internasional yang cukup rumit yang ketentuan-ketentuan pokoknya termuat dalam General Agreement On Tariffs and Trade (GATT) yang ditandatangani negara-negara pada tahun 1947. Disepakatinya GATT didasarkan pada pertimbangan bahwa hubungan antar negara di bidang perdagangan dan ekonomi harus dijalankan dengan sasaran untuk meningkatkan standar hidup, menjamin lapangan kerja dan meningkatkan penghasilan dan pemenuhan kebutuhan, pemanfaatan sumber-sumber daya dunia sepenuhnya, serta memperluas produksi serta pertukaran barang.

Terbentuknya WTO mulai 1 Januari 1995 maka persoalan tentang apakah GATT sebuah organisasi internasional atau bukan, kini telah berakhir. GATT 1947 kini diintegrasikan ke dalam salah satu perjanjian yang merupakan annex perjanjian WTO yakni Multilateral Agreement On Trade

1 Akbar Kurnia Putra, Agreement on Agriculture dalam World Trade Organization. Jurnal Hukum dan Pembangunan. Vol. 46, No. 1, 5 Maret 2016, hal. 97.

2 Huala Adolf. Hukum Perdagangan Internasional. PT Raja Grafindo Persada, 2006, hal. 37.

Uti Possidetis: Journal of International Law, Vol. 2, No. 1 (2021) 
In Goods. Untuk mencapai tujuan-tujuan ini diadakanlah suatu pengaturan yang saling menguntungkan yang diarahkan pada pengurangan tarif secara substansial dan juga hambatanhambatan non-tarif terhadap perdagangan, dan untuk menghilangkan perlakuan diskriminatif dalam hubungan perdagangan internasional. ${ }^{3}$

WTO berfungsi untuk mengatur dan memfasilitasi perdagangan internasional. ${ }^{4}$ Perjanjian yang diatur dalam WTO iantara lain meliputi Perjanjian Pertanian AOA), Perjanjian sektor Jasa (GATS), Perjanjian HAKI terkait Perdagangan (TRIPS), Perjanjian Akses Pasar Non Pertanian (NAMA) dan isu investasi termasuk Perjanjian Investasi terkait Perdagangan (TRIMS). Organisasi perdagangan dunia atau WTO yang saat ini sudah tidak lagi mengenai soal perdagangan barang saja (sebagaimana yang ada di GATT, pendahulu WTO sebelumnya), melainkan telah meluas ke berbagai sektor ekonomi dan kehidupan manusia, seperti pada pertanian, hak atas kekayaan intelektual (HAKI) atau ilmu pengetahuan, investasi, sektor jasa-jasa dan lain-lainnya. ${ }^{5}$

Fungsi WTO yang terpenting adalah melancarkan pelaksanaan, pengadministrasian dan lebih meningkatkan tujuan dari perjanjian pembentukan WTO sendiri serta perjanjian-perjanjian lain yang terkait dengannya. Di samping itu WTO merupakan forum negosiasi bagi para anggotanya di bidang-bidang yang menyangkut perdagangan multilateral, forum penyelesaian sengketa. ${ }^{6}$

Cara untuk mencapai tujuan-tujuan ini adalah dengan mengadakan pengaturan timbal balik dan saling

3 Hata, Perdagangan Internasional dalam Sistem GATT dan WTO, Cet. Pertama, PT Refika Aditama, Bandung, 2006, hal. 87-88.

4 Revy S. M. Korah. Prinsip-Prinsip Eksistensi General Agreement On Tariffs And Trade (GATT) Dan World Trade Organization (WTO) Dalam Era Pasar Bebas. Jurnal Hukum UNSRAT Vol. 22, No. 7 Agustus 2016, hal. 49.

5 Dewi Nurul Musjtari. Dampak Liberalisasi Perdagangan Dalam WTOAgreement Terhadap Ketahanan Pangan Indonesia. Kanun Jurnal Ilmu Hukum No. 63 Agustus 2014, hal. 224-225.

6 Hata, Perdagangan Internasional dalam Sistem GATT dan WTO, Loc. Cit. 
menguntungkan untuk mengurangi tarif dan hambatanhambatan perdagangan lain, serta menghilangkan diskriminasi dalam perdagangan internasional. Sebagai bagian dari Final Act Putaran Uruguay, negara-inegara anggota GATT bersepakat untuk mengakui suatu realita, dan mulai 1 Januari 1995 membentuk sebuah organisasi perdagangan dunia bernama World Trade Organization (WTO). ${ }^{7}$

Hadirnya organisasi dagang dunia yang dikenal sebagai WTO melahirkan berbagai ketentuan yang mewarnai perdagangan internasional, menempatkan organisasi ini sebagai organisasi berpengaruh dalam perdagangan internasional. Selanjutnya, Indonesia sebagai bagian dari masyarakat internasional yang ikut bergabung dalam organisasi perdagangan internasional atau WTO harus mengikuti aturan-aturan atau kaidah-kaidah yang ada di dalam organisasi tersebut. Kaidah-kaidah WTO tersebut dituangkan ke dalam hukum nasional, lalu Indonesia telah meratifikasi (pengesahan) persetujuan pembentukan WTO melalui Undang-Undang Nomor 7 Tahun 1994 Tentang Pengesahan Agreement Establishing The World Trade Organization (Persetujuan Pembentukan Organisasi Perdagangan Dunia). ${ }^{8}$

Adanya perjanjian ini, negara-negara di dunia dapat ikut bergabung dalam WTO dan juga tidak, keikutsertaan dalam WTO tergantung pada negara itu sendiri, pada kaidah-kaidah internasional sebagaimana diatur oleh WTO, termasuk penyelesaian perselisihan perdagangan internasional yang lebih efektif. ${ }^{9}$

Keanggotaan Indonesia pada organisasi internasional diamanatkan untuk memperoleh manfaat yang maksimal bagi kepentingan nasional. ${ }^{10}$ Prinsip pembentukan dan dasar WTO

\footnotetext{
${ }^{7}$ Hata, Perdagangan Internasional dalam Sistem GATT dan WTO, Loc. Cit.

${ }^{8}$ Soedjono Dirdjosisworo, Pengantar Hukum Dagang Internasional, Cet. Pertama, PT Refika Aditama, Bandung, 2006, hal. 133.

${ }^{9}$ Mochtar Kusumaatmadja dan Etty R. Agoes, Pengantar Hukum Internasional, Cet. kedua, P.T. Alumni, Jakarta, 2018, hal. 10. ${ }^{10}$ Jessi Garfield Sawy. Dampak Persetujuan World Trade Organization Terhadap Kebijakan Investasi dan Perdagangan (Studi Kasus: Keberatan
} 
adalah untuk mengupayakan keterbukaan batas wilayah, memberikan jaminan atas "most-favored-nation principle" (MFN) dan perlakuan non-diskriminasi oleh dan di antara negara anggota, serta komitmen terhadap transparansi dalam semua kegiatannya. ${ }^{11}$

Keikutsertaan Indonesia dalam WTO dalam pelaksanaan berbagai kebijaksanaan di sektor perdagangan internasional. Berbagai persetujuan hasil dari perundingan putaran Uruguay yang disepakati di Marrakesh merupakan kesepakatan untuk memperbaiki situasi hubungan perdagangan internasional melalui upaya memperluas akses pasar barang dan jasa, menyempurnakan berbagai peraturan perdagangan, memperluas cakupan dari ketentuan GATT, dan memperbaiki kelembagaan atau institusi perdagangan multilateral. Dengan demikian, diharapkan perekonomian nasional dengan perekonomian dunia semakin terintegrasi.

Tata cara perdagangan dalam negeri berbeda dengan perdagangan internasional. Hal itu disebabkan oleh faktorfaktor tertentu antara lain perbedaan mata uang, mata uang setiap negara berbeda antara satu dengan yang lain, faktor selanjutnya, pembeli dan penjual terpisah oleh batas-batas kenegaraan, barang harus dikirim atau diangkut dari satu negara ke negara lainnya melalui bermacam peraturan, seperti peraturan pabean. Peraturan-peraturan ini mengandung berbagai pembatasan yang dikeluarkan oleh masing-masing pemerintah sehingga antara satu negara dengan negara lainnya tidak jarang terdapat perbedaan dalam hukum, takaran dan timbangan, mata uang dan lain sebagainya. ${ }^{12}$

Perdagangan antar negara untuk melindungi pertumbuhan sektor ekonomi dalam negeri, misalnya untuk melindungi sektor industri dan pertanian atau mungkin juga untuk tujuan penghematan pemakaian devisa negara sehingga perdagangan internasional dibatasi pada barang yang sangat

Anggota WTO Terhadap Undang-Undang Mineral dan Batu Bara No. 4/2009). Kanun Jurnal Ilmu Hukum. Vol. 2, No. 1, 2018, hal. 2.

${ }^{11}$ Revy S. M. Korah, Op.Cit, hal. 50.

${ }^{12}$ M. E. Retno Kadarukmi. Dampak Implementasi GATT/WTO Terhadap Ekspor Impor Indonesia. Jurnal Administrasi Bisnis Vol. 9, No. 1, 2013, hal. 82 . 
perlu saja. Pembatasan semacam ini dapat dianggap sebagai pembatasan yang didasarkan pada pertimbangan ekonomi semata dan bukan untuk mencapai tujuan politik luar negeri tertentu. Di samping itu, masih terdapat pembatasan yang dilakukan secara tidak langsung, misalnya dengan penetapan bea masuk yang tinggi ataupun dengan mempersulit pemberian izin untuk jenis barang tertentu. Cara semacam ini lebih tepat dikatakan sebagai cara mencapai tujuan fiskal. ${ }^{13}$

Langkah pemerintah Indonesia sebagai salah satu anggota World Trade Organization (WTO) antara lain dengan mengeluarkan Undang-Undang Nomor 7 Tahun 2014 Tentang Perdagangan, menggantikan produk hukum kolonial Bedrijfsregmenterings Ordonanntie 1934 yang lebih banyak mengatur perizinan usaha. ${ }^{14}$

Berdasarkan tujuan tersebut, Undang-Undang Nomor 7 Tahun 2014 Tentang Perdagangan memuat materi pokok sesuai dengan lingkup pengaturan yang meliputi perdagangan dalam negeri, perdagangan luar negeri, perdagangan perbatasan, standardisasi, perdagangan melalui sistem elektronik, perlindungan dan pengamanan perdagangan, pemberdayaan koperasi serta usaha mikro, kecil, dan menengah, pengembangan ekspor, kerja sama perdagangan internasional, sistem informasi perdagangan, tugas dan wewenang pemerintah di bidang perdagangani, komite perdagangan nasional, pengawasan, serta penyidikan. ${ }^{15}$

Undang-Undang Nomor 7 Tahun 2014 Tentang Perdagangan dibuat dengan mengedepankan kepentingan nasional dan ditujukan untuk melindungi pasar domestik dan produk dalam negeri, membuat regulasi perdagangan dalam negeri dan memberikan perlindungan terhadap konsumen. ${ }^{16}$

\footnotetext{
${ }^{13}$ Ibid

${ }^{14}$ Syukri Hidayatullah,. Perbandingan Hukum Pengaturan Standardisasi

Menurut Agreement TBT dan Undang-Undang No. 7 Tahun 2014

Tentang Perdagangan. Arena Hukum Vol. 9 No. 2 Agustus 2016, hal. 272-273.

${ }^{15}$ Lihat Undang-Undang Nomor 7 Tahun 2014 Tentang Perdagangan. ${ }^{16} \mathrm{http}$ ://evitays.blogspot.com/2017/05/uu-no-7-tahun-2014-tentangperdagangan.html?m=1. Diakses pada tanggal 10 Februari 2020, Pukul 22:37 WIB
} 
Isi Pasal 22 dan Pasal 25 Undang-Undang Nomor 7 Tahun 2014 Tentang Perdagangan, memuat materi yang bertentangan dengan salah satu prinsip World Trade Organization (WTO) yakni persaingan bebas (asymmetric economic conditions, empowering, free competition).

Pasal 22 dan Pasal 25 Undang-Undang Nomor 7 Tahun 2014 Tentang Perdagangan, menetapkan pemerintah melakukan keberpihakan melalui promosi, sosialisasi, atau pemasaran dan menerapkan kewajiban menggunakan produk dalam negeri. Sedangkan, prinsip persaingan bebas (asymerical economic conditionsi, empoweringi, free competition) adalah gagasan tentang keharusan memperhatikan kondisi asimetris masyarakat internasional, penyetaraan daya saingi, dan persaingan bebas iyang dikemukakan oleh Adam Smith. ${ }^{17}$

Sangat terlihat jelas bahwa Undangi-Undang tersebut dijadikan sebagai bentuk protect pemerintah bagi sistem perekonomian nasional. Lalu ikemudian, ibagaimana dengan prinsip perdagangan internasional World Trade Organization (WTO) yang bertentangan dengan Undang-Undang tersebut. Apakah Undang-Undang tersebut dapat mempengaruhi keberadaan Indonesia sebagai salah satu anggota WTO.

Berdasarkan uraian di atas maka penulis tertarik melakukan penelitian yang dituangkan dalam suatu karya ilmiah yang berjudul "Harmonisasi Prinsip-Prinsip Perdagangan Internasional World Trade Organization (WTO) Dalam Undang-Undang Nomor 7 Tahun 2014 Tentang Perdagangan".

Berdasarkan latar belakang masalah yang telah diuraikan sebelumnya dan dari hasil penelusuran yang telah dilakukan oleh penulis, bahwa di dalam Pasal 22 dan Pasal 25 Undang-Undang Nomor 7 Tahun 2014 Tentang Perdagangan, menetapkan pemerintah melakukan keberpihakan melalui promosi, sosialisasi, atau pemasaran dan menerapkan kewajiban menggunakan produk dalam negeri. Sedangkan, prinsip persaingan bebas (asymerical economic conditionsi, empowering, free competition) adalah gagasan tentang

\footnotetext{
${ }^{17}$ Ida Bagus Wyasa Putra, Ni Ketut Supasti Dharmawan, Loc. Cit.
} 
keharusan memperhatikan kondisi asimetris masyarakat internasional, penyetaraan daya saing, dan persaingan bebas yang dikemukakan oleh Adam Smith. Oleh sebab itu, adapun yang menjadi perumusan masalah dalam penulisan karya ilmiah skripsi ini adalah:

Bagaimanakah implementasi prinsip-prinsip perdagangan internasional (WTO) dan Undang-Undang Nomor 7 Tahun 2014 Tentang Perdagangan?

Bagaimanakah harmonisasi prinsip-prinsip perdagangan internasional World Trade Organization (WTO) dalam Undangi-Undang Nomor i7 Tahun 2014 Tentang Perdagangan?

\section{B. Pembahasan dan Analisis}

1. Implementasi Prinsip Hukum dalam Pengaturan Perdagangan Internasional pada General Agreement on Tariffs and Trade (GATT) dan Undang-Undang Nomor 7 Tahun 2014 Tentang Perdagangan.

Penerapan prinsip-prinsip WTO ditujukan untuk menghasilkan kondisi-kondisi yang bersifat timbal balik dan saling menguntungkan sehingga semua negara dapat menarik manfaatnya. Melalui WTO, diluncurkan suatu model perdagangan dimana kegiatan perdagangan antar negara diharapkan dapat berjalan dengan lancar. Pada prinsipnya World Trade Organization (WTO) merupakan suatu sarana untuk mendorong terjadinya suatu perdagangan bebas yang tertib dan adil di dunia ini. Dalam menjalankan tugasnya untuk mendorong terciptanya perdagangan bebas tersebut, World Trade Organization (WTO) memberlakukan beberapa prinsip yang menjadi pilar-pilar World Trade Organization (WTO). ${ }^{18}$

Berdasarkan Undang-Undang Nomor 7 Tahun 1994 Tentang Pengesahan Agreement Establishing The World Trade Organization (Persetujuan Pembentukan Organisasi Perdagangan Dunia) terdapat isi atau materi yang memuat pengaturan prinsip WTO, yakni pada huruf $A, B$, dan C. Pada huruf $A, B$ dan $C$ berbunyi:

18 Revy S. M. Korah, Op.Cit, hal. 48.

Uti Possidetis: Journal of International Law, Vol. 2, No. 1 (2021) 
a. Bahwa pembangunan nasional bertujuan untuk memwujudkan suatu masyarakat adil dan makmur yang merata materiel dan spiritual berdasarkan Pancasila dan Undang-Undang Dasar 1945 dalam wadah Negara Kesatuan Republik Indonesia yang merdeka, bersatu, berdaulat dan berkedaulatan rakyat dalam suasana perikehidupan bangsa yang aman, tenteram, tertib, dan dinamis dalam lingkungan pergaulan dunia yang merdeka, adil, bersahabat, tertib, dan damai;

b. Bahwa dalam pelaksanaan pembangunan nasional, khususnya di bidang ekonomi, diperlukan upaya-upaya untuk antara lain terus meningkatkan, memperluas, memantapkan dan mengamankan pasar bagi segala produk baik barang maupun jasa, termasuk aspek investasi dan hak atas kekayaan intelektual yang berkaitan dengan perdagangan, serta meningkatkan kemampuan daya saing terutama dalam perdagangan internasional;

c. Bahwa seiring dengan cita-cita sebagaimana disebutkan huruf a dan b di atas, Indonesia selalu berusaha menegakkan prinsip-prinsip pokok yang dikandung dalam General Agreement on Tariff and Trade/ GATT 1947 (Persetujuan Umum mengenai Tarif dan Perdagangan Tahun 1947) berikut persetujuan susulan yang telah dihasilkan sebelum Putaran Uruguay. ${ }^{19}$

Penjelasan atas Undang-Undang Nomor 7 Tahun 1994 Tentang Pengesahan Agreement Establishing The World Trade Organization (Persetujuan Pembentukan Organisasi Perdagangan Dunia), General Agreement on Tariffs and Trade/GATT (Persetujuan Umum mengenai Tarif dan Perdagangan) merupakan perjanjian perdagangan multilateral dengan tujuan menciptakan perdagangan bebas, adil, dan membantu menciptakan pertumbuhan ekonomi dan pembangunan guna mewujudkan kesejahteraan umat manusia.

${ }^{19}$ Lihat Undang-Undang Nomor 7 Tahun 1994 Tentang Pengesahan Agreement Establishing The World Trade Organization (Persetujuan pembentukan Organisasi Perdagangan Dunia) 
GATT dimaksudkan sebagai upaya untuk memperjuangkan terciptanya perdagangan bebas, adil, dan menstabilkan sistem perdagangan internasional, dan memperjuangkan penurunan tarif sebagai tatanan multilateral yang memuat prinsip-prinsip perdagangan internasional, GATT menetapkan kaidah bahwa hubungan perdagangan antar negara dilakukan tanpa diskriminasi (non discrimination). Hal ini berarti, suatu negara yang tergabung dalam GATT tidak diperkenankan untuk memberikan perlakuan khusus bagi negara tertentu. Setiap negara harus memberikan perlakuan yang sama dan timbal balik dalam hubungan perdagangan internasional.

GATT berfungsi sebagai forum konsultasi negaranegara anggota dalam membahas dan menyelesaikan masalahmasalah yang timbul di bidang perdagangan internasional, GATT juga berfungsi sebagai forum penyelesaian sengketa di bidang perdagangan antara negara-negara peserta. GATT juga merupakan forum untuk mengajukan keberatan dari suatu negara yang merasa dirugikan atau mendapat perlakuan yang tidak adil dari negara peserta yang lain di bidang perdagangan. Prinsipnya, masalah-masalah yang timbul diselesaikan secara bilateral antara negara-negara yang terlibat dalam persengketaan dagang melalui konsultasi dan konsiliasi, serta hasilnya diberitahukan kepada GATT. 20

Penerapan Undang-Undang Nomor 7 Tahun 2014 Tentang Perdagangan memuat diantaranya perdagangan dalam negeri dan perdagangan luar negeri yang tidak membeda-bedakan setiap pelaku usaha. Setiap pelaku usaha wajib mematuhi Undang-Undang Nomor 7 Tahun 2014 Tentang Perdagangan tersebut tanpa adanya diskriminasi atau keberpihakan. ${ }^{21}$ Pada Undang-Undang Nomor 7 Tahun 2014 Tentang Perdagangan salah satunya juga memuat larangan dan pembatasan perdagangan barang dan/atau jasa yang

20 Lihat Penjelasan Atas Undang-Undang Nomor 7 Tahun 1994 Tentang Pengesahan Agreement Establishing The World Trade Organization (Persetujuan pembentukan Organisasi Perdagangan Dunia)

${ }^{21}$ Lihat Undang-Undang Nomor 7 Tahun 2014 Tentang Perdagangan

Uti Possidetis: Journal of International Law, Vol. 2, No. 1 (2021) 
berlaku bagi setiap pelaku usaha. Di samping itu, UndangUndang ini memuat standardisasi yang mana ketentuan standardisasi di dalam Undang-Undang tersebut berlaku bagi setiap pelaku usaha.

Undang-Undang ini pun memuat perlindungan dan pengamanan perdagangan serta pemberdayaan koperasi serta usaha mikro, kecil dan menengah yang ketentuannya harus dipatuhi setiap pelaku usaha tanpa membeda-bedakan pelaku usaha itu sendiri dalam hal ini berlaku menyeluruh. ${ }^{22}$

\section{Harmonisasi Prinsip-Prinsip Perdagangan Internasional pada General Agreement on Tariffs and Trade (GATT) dengan Undang-Undang Nomor 7 Tahun 2014 Tentang Perdagangan}

Pengaturan Kedaulatan Negara (Sovereignity) dalam Prinsip Perdagangan Internasional WTO, sistem kelembagaan dan sistem hukum WTO menempatkan prinsip kedaulatan negara sebagai prinsip utama sistem kelembagaan dan sistem hukumnya. Undang-Undang Nomor 7 Tahun 2014 Tentang Perdagangan mengatur, secara spesifik tertuang di dalam Pasal 5 ayat (1) Undang-Undang Nomor 7 Tahun 2014 Tentang Perdagangan terletak pada Bab IVPerdagangan Dalam Negeri, bagian kesatu mengenai umum:

Pemerintah mengatur kegiatan Perdagangan Dalam Negeri melalui kebijakan dan pengendalian.23 Prinsip selanjutnya, pengaturan Kesederajatan Negara (Equal State) dalam Prinsip Perdagangan Internasional WTO mencakup di dalam paham kedaulatan ini adalah kemerdekaan dan persamaan derajat, artinya bahwa negara-negara yang berdaulat itu adalah naegara yang merdeka (independence) juga memiliki kesamaan derajat (equality) satu dengan lainnya. ${ }^{24}$ Undang-Undang Nomor 7 Tahun 2014 Tentang Perdagangan mengatur, secara spesifik tertuang di dalam Pasal 49 ayat (1) Undang-Undang Nomor 7 Tahun 2014

\footnotetext{
22 Ibid

23 Lihat Undang-Undang Nomor 7 Tahun 2014 Tentang Perdagangan

24 Siti Sumartini, Loc. Cit.
} 
Tentang Perdagangan terletak pada Bab $V$ Perdagangan Luar Negeri, bagian keempat mengenai Perizinan Ekspor dan Impor:

Untuk kegiatan Ekspor dan Impor, Menteri mewajibkan Eksportir dan Importir untuk memiliki perizinan yang dapat berupa persetujuan, pendaftaran, penetapan, dan/atau pengakuan. ${ }^{25}$

Pengaturan prinsip lainnya yakni Persaingan Bebas (Asymmetric Economic Conditions, Empowering, Free Competition) dalam Prinsip Perdagangan Internasional WTO, gagasan tentang keharusan memperhatikan kondisi asimetris masyarakat internasional, penyetaraan daya saing, dan persaingan bebas berasal dari Adam Smith bahwa persaingan terbuka dalam liberalisasi perdagangan dapat dilakukan hanya jika persyaratan untuk persaingan demikian itu telah dipenuhi. Undang-Undang Nomor 7 Tahun 2014 Tentang Perdagangan mengatur, secara spesifik tertuang di dalam Pasal 22 ayat (1), (2), dan (3) Undang-Undang Nomor 7 Tahun 2014 terletak pada Bab IV bagian kelima Peningkatan Penggunaan Produk Dalam Negeri, menjelaskan bahwa:

(1) Dalam rangka pengembangan, pemberdayaan dan penguatan Perdagangan Dalam Negeri, Pemerintah, Pemerintah Daerah, dan/atau pemangku kepentingan lainnya secara sendiri-sendiri atau bersama-sama mengupayakan peningkatan penggunaan Produk Dalam Negeri.

(2) Peningkatan penggunaan Produk Dalam Negeri sebagaimana dimaksud pada ayat (1) dilakukan keberpihakan melalui promosi, sosialisasi atau pemasaran dan menerapkan kewajiban menggunakan Produk Dalam Negeri sesuai dengan ketentuan peraturan perundangundangan.

(3) Ketentuan lebih lanjut mengenai peningkatan penggunaan Produk Dalam Negeri diatur dengan Peraturan Menteri. ${ }^{26}$

25 Lihat Undang-Undang Nomor 7 Tahun 2014 Tentang Perdagangan 26 Ibid

Uti Possidetis: Journal of International Law, Vol. 2, No. 1 (2021) 
Prinsip utama dalam World Trade Organization (WTO) yaitu Diskriminasi dan Non-Diskriminasi (Discriminationn Non-discrimination) dalam Prinsip Perdagangan Internasional WTO, Prinsip non-diskriminasi yang terdapat dalam GATS jauh lebih spesifik dan berskala global yang meliputi Most Favoured Nation (MFN), National Treatment. Prinsip MFN diatur dalam article II GATS yang pada intinya mengatur setiap anggota GATS harus dengan tanpa syarat memberikan perlakuan yang tidak berbeda (no less favourable) kepada penyedia jasa dari dalam ataupun luar negeri dengan secepatnya. Sedangkan pengaturan prinsip National Treatmentterdapat dalam Pasal XVIIGATS yang mensyaratkan negara peserta GATS memberikan perlakuan yang sama antara jasa antara negara warga negara sendiri ataupun warga negara asing. ${ }^{27}$ Undang-Undang Nomor 7 Tahun 2014 Tentang Perdagangan mengatur, secara spesifik tertuang di dalam Pasal 37 ayat (1) dan (2) Undang-Undang Nomor 7 Tahun 2014 Tentang Perdagangan terletak pada Bab IV Perdagangan Dalam Negeri, bagiam kesembilan mengenai Larangan dan Pembatasan Perdagangan Barang dan/atau Jasa, menjelaskan bahwa:

(1) Setiap Pelaku Usaha wajib memenuhi ketentuan penetapan Barang dan/atau Jasa yang dibatasi Perdagangannya sebagaimana dimaksud dalam Pasal 35 ayat (2).

(2) Setiap Pelaku Usaha yang melanggar ketentuan penetapan Barang dan/atau Jasa sebagaimana dimaksud pada ayat (1) dikenai sanksi administratif berupa pencabutan perizinan di bidang Perdagangan. ${ }^{28}$

Prinsip selanjutnya yakni Pengecualian dan Perlakuan Khusus (Exception, Special Treatment) dalam Prinsip Perdagangan Internasional WTO, pengecualian dan perlakuan khusus dapat dilakukan dalam memenuhi kepentingan nasional, seperti: meningkatkan taraf hidup rakyat, mempertahankan keseimbangan ekonomi, mengatasi kesulitan ekonomi dari tekanan ekonomi, dan lain-lain. ${ }^{29}$

\footnotetext{
27 A.A. Istri Eka Krisna Yanti, Loc. Cit.

${ }^{28}$ Lihat Undang-Undang Nomor 7 Tahun 2014 Tentang Perdagangan

${ }^{29}$ Ida Bagus Wyasa Putra, Ni Ketut Supasti Dharmawan, Loc. Cit.
} 
Undang-Undang Nomor 7 Tahun 2014 Tentang Perdagangan mengatur, secara spesifik tertuang di dalam Pasal 50 ayat (2) Undang-Undang Nomor 7 Tahun 2014 Tentang Perdagangan terletak pada Bab $V$ Perdagangan Luar Negeri bagian kelima mengenai Larangan Pembatasan Ekspor dan Impor, menjelaskan bahwa:

Pemerintah melarang Impor atau Ekspor Barang untuk kepentingan nasional dengan alasan:

a. Untuk melindungi keamanan nasional atau kepentingan umum, termasuk sosial, budaya, dan moral masyarakat;

b. Untuk melindungi hak kekayaan intelektual; dan/atau

c. Untuk melindungi kesehatan dan keselamatan manusia, hewan, ikan, tumbuhan, dan lingkungan hidup. ${ }^{30}$

Adapun prinsip Timbal-Balik (Reciprocity) dalam Prinsip Perdagangan Internasional WTO, mewajibkan setiap negara anggota yang menikmati konsesi dari negara anggota yang lain (penerima konsesi), untuk memberikan konsesi yang sama kepada negara anggota pemberi konsesi. ${ }^{31}$ Hakikatnya, prinsip resiprositas memiliki keterkaitan erat dengan prinsip non diskriminasi sebagaimana diatur dalam World Trade Organization (WTO).

Sistem WTO menentukan adanya kewajiban pemberian perlakuan secara seimbang antar negara anggota. Pemberian perlakuan secara seimbang ini menjadi bagian tidak terpisahkan dari upaya perwujudan sistem perdagangan yang lebih bebas. Perdagangan dalam konteks ini mencakup perdagangan barang dan jasa. Prinsip resiprositas dapat dilaksanakan oleh negara-negara yang telah melakukan perjanjian bilateral.

Pemberlakuan prinsip resiprositas tidak bersifat sertamerta tanpa syarat. Berbeda dengan prinsip non diskriminasi sebagimana diatur dalam WTO, pemberlakuan prinsip resiprositas didasarkan pada terpenuhinya dua syarat. Pertama, yakni tercapainya perjanjian bilateral antar negara

${ }^{30}$ Lihat Undang-Undang Nomor 7 Tahun 2014 Tentang Perdagangan ${ }^{31}$ Ida Bagus Wyasa Putra, Ni Ketut Supasti Dharmawan, Loc. Cit. 
anggota atas dasar kesiapan. Kedua, terpenuhinya kualifikasi bagi negara-negara anggota World Trade Organization (WTO). ${ }^{32}$ Undang-Undang Nomor 7 Tahun 2014 Tentang Perdagangan mengatur, secara spesifik tertuang di dalam Pasal 48 Undang-Undang Nomor 7 Tahun 2014 Tentang Perdagangan terletak pada Bab $V$ Perdagangan Luar Negeri bagian ketiga mengenai impor, menjelaskan bahwa:

Surat persetujuan Impor atas Barang dalam keadaan tidak baru sebagaimana dimaksud dalam Pasal 47 ayat (2) diserahkan pada saat menyelesaikan kewajiban pabean sesuai dengan ketentuan peraturan perundang-undangan di bidang Kepabeanan. ${ }^{33}$

Prinsip yang terakhir yakni Penyelesaian Sengketa secara Damai (Peaceful Settlement of Dispute) dalam Prinsip Perdagangan Internasional WTO, setiap negara anggota wajib menyelesaikan sengketa di antara mereka dengan cara damai. ${ }^{34}$ Penyelesaian sengketa secara damai dilakukan dalam bentuk diantaranya negosiasi, jasa-jasa baik, mediasi penengahan, konsiliasi, konperensi internasional, inkuiri komisi pemeriksaan/pencari fakta. Penyelesaian sengketa secra damai dalam WTO diatur dalam Understanding on Rules and Procedures Governing the Settlement of Disputes/DSU (Disputes Settlement Understanding). ${ }^{35}$ Undang-Undang Nomor 7 Tahun 2014 Tentang Perdagangan mengatur, secara spesifik tertuang di dalam Pasal 38 ayat (3) Undang-Undang Nomor 7 Tahun 2014 Tentang Perdagangan terletak pada Bab $V$ Perdagangan Luar Negeri bagian kesatu mengenai umum, menjelaskan bahwa:

Kebijakan Perdagangan Luar Negeri paling sedikit meliputi:

a. Peningkatan jumlah dan jenis serta nilai tambah produk ekspor;

b. Pengharmonisasian Standar dan prosedur kegiatan Perdagangan dengan negara mitra dagang;

c. Penguatan kelembagaan di sektor Perdagangan Luar Negeri;

\footnotetext{
32 Inda Rahadiyan, Loc.Cit.

33 Lihat Undang-Undang Nomor 7 Tahun 2014 Tentang Perdagangan

34 Ida Bagus Wyasa Putra, Ni Ketut Supasti Dharmawan, Loc. Cit.

35 Imawan Dicky Prasudhi, Loc. Cit.
} 
d. Pengembangan sarana dan prasarana penunjang Perdagangan Luar Negeri; dan

e. Perlindungan dan pengamanan kepentingan nasional dari dampak negatif Perdagangan Luar Negeri. ${ }^{36}$

Berdasarkan Undang-Undang Nomor 24 Tahun 2000 Tentang Perjanjian Internasional memuat isi atau materi pemberlakuan asas-asas hukum internasional, yakni di Pasal 10 menjelaskan bahwa:

Pengesahan perjanjian internasional dilakukan dengan undang-undang apabila berkenaan dengan:

a. Masalah politik, perdamaian, pertahanan, dan keamanan negara;

b. Perubahan wilayah atau penetapan batas wilayah negara Republik Indonesia;

c. Kedaulatan atau hak berdaulat negara;

d. Hak asasi manusia dan lingkungan hidup;

e. Pembentukan kaidah hukum baru;

f. Pinjaman dan/atau hibah luar negeri. ${ }^{37}$

Indonesia sebelum mengikatkan diri atau menyatakan persetujuan terikat pada suatu perjanjian internasional sebagaimana lazimnya, akan mengkaji secara mendalam terlebih dahulu substansi dari perjanjian internasional itu.

Masuknya atau berlakunya suatu perjanjian internasional ke dalam hukum nasional Indonesia dapat menimbulkan berbagai dampak terhadap hukum atau peraturan perundang-undangan yang terkait. Persoalanpersoalan yang terkait dalam hal ini adalah, sejauh manakah substansi perjanjian internasional itu sesuai ataupun bertentangan dengan kepentingan nasional ataupun hukum atau peraturan perundang-undangan nasional dalam bidang yang bersangkutan, sejauh manakah peraturan perundangundangan nasional harus diubah dan disesuaikan dengan perjanjian internasional itu, adakah ketentuan perjanjian internasional itu bertentangan atau tidak sesuai dengan

\footnotetext{
36 Lihat Undang-Undang Nomor 7 Tahun 2014 Tentang Perdagangan 37 Lihat Undang-Undang Nomor 24 Tahun 2000 Tentang Perjanjian Internasional
}

Uti Possidetis: Journal of International Law, Vol. 2, No. 1 (2021) 
kepentingan nasional atau dengan peraturan perundangundangan yang substansinya sangat fundamental dan karena itu perlu diajukan pensyaratan (reservation), bagaimana penjabaran substansi perjanjian internasional itu ke dalam hukum atau peraturan perundang-undangan nasional Indonesia. ${ }^{38}$

Dalam hukum perjanjian internasional, kepentingan negara-negara pihak/peserta dengan kedaulatannya masingmasing diakomodasi dengan memberikan hak pada negaranegara tersebut untuk menolak ataupun memberikan pengertian lain atas ketentuan tertentu dari perjanjian internasional berdasarkan atas kepentingan subyektif dari negara itu sendiri. Inilah yang dikenal dengan sebutan pensyaratan (reservation) yang pada hakekatnya merupakan tindakan sepihak (unilateral act).

Terhadap pensyaratan ini, negara-negara pihak/peserta lain yang juga memiliki kedaulatan, juga diberikan hak untuk menyetujui ataupun menolak/keberatan terhadap pensyaratan yang diajukan oleh salah satu negara pihak/peserta. Bahkan semua negara pihak/peserta yang memberikan/membuat atau menerima/menolak pensyaratan juga diberikan hak untuk menarik kembali penolakan terhadap pensyaratan tersebut dengan segala konsekuensi hukumnya. Semua itu harus dipandang sebagai manifestasi pengakuan hukum perjanjian internasional atas kedaulatan negara. ${ }^{39}$

Formulasi yang lebih bebas, pensyaratan itu dapat pula didefinisikan sebagai berikut, Pernyataan sepihak yang dikemukakan oleh suatu negara pada waktu menyatakan persetujuan untuk terikat pada suatu perjanjian internasional, yang isinya menyatakan:

38 I Wayan Parthiana. Kajian Akademis (Teoritis dan Praktis) atas Undang-Undang Nomor 24 Tahun 2000 Tentang Perjanjian Internasional Berdasarkan Hukum Perjanjian Internasiona. Jurnal Hukum Internasional. Vol. 5, No. 3, April 2008, hal. 474-475.

39 I Wayan Parthiana. Beberapa Masalah dalam Pengimplementasian Kewajiban Negara Indonesia di Bawah Perjanjian Internasional. $O p$. Cit, hal. 168. 
a) Menolak untuk menerima atau mengakui atau tidak mau terikat pada, atau tidak mau menerima akibat hukum dari salah satu atau beberapa ketentuan dari perjanjian tersebut dan/atau;

b) Mengubah atau menyesuaikan isi atau memberikan arti tersendiri atas salah satu atau beberapa ketentuan dari perjanjian tersebut sesuai dengan kepentingan negara yang bersangkutan..$^{40}$

Undang-Undang Nomor 24 Tahun 2000 Tentang Perjanjian Internasional pada Pasal 8 ayat (1), (2), dan (3) mengatur pensyaratan perjanjian internasional bagi Indonesia:

(1) Pemerintah Republik Indonesia dapat melakukan pensyaratan dan / atau pernyataan, kecuali ditentukan lain dalam perjanjian internasional tersebut.

(2) Pensyaratan dan pernyataan yang dilakukan pada saat penandatangan perjanjian internasional harus ditegaskan kembali pada saat pengesahan perjanjian tersebut.

(3) Pensyaratan dan pernyataan yang ditetapkan Pemerintah Republik Indonesia dapat ditarik kembali setiap saat melalui pernyataan tertulis atau menurut tata cara yang ditetapkan dalam perjanjian internasional.

Pensyaratan dan Pernyataan dilakukan atas perjanjian internasional yang bersifat multilateral dan dapat dilakukan atas suatu bagian perjanjian internasional sepanjang pensyaratan dan pernyataan tersebut tidak bertentangan dengan maksud dan tujuan dibuatnya perjanjian internasional tersebut. Dengan pensyaratan atau pernyataan terhadap suatu ketentuan perjanjian internasional, Pemerintah Republik Indonesia secara hukum tidak terikat pada ketentuan tersebut. 41

Ratifikasi Undang-Undang Nomor 7 Tahun 1994 Tentang Pengesahan Agreement on Establishing the World

\footnotetext{
40 I Wayan Parthiana, Hukum Perjanjian Internasional, Cet. Pertama, CV. Mandar Maju, Bandung, 2018, hal. 152.

41 Lihat Undang-Undang Nomor 24 Tahun 2000 Tentang Perjanjian Internasional
} 
Trade Organization oleh Indonesia merupakan langkah yang menunjukkan sikap pemerintah untuk berpartisipasi dalam perdagangan global. Terciptanya Undang-Undang Nomor 7 Tahun 2014 Tentang Perdagangan merupakan langkah konkrit Pemerintah Indonesia untuk terjun langsung dalam menghadapi ekonomi global. Lingkup dari Undang-Undang Nomor 7 Tahun 2014 Tentang Perdagangan mencakup aspekaspek perdagangan baik luar negeri maupun dalam negeri tentunya tidak terlepas dari ketentuan-ketentuan World Trade Organization (WTO).

Pasal 38 ayat (3) Undang-Undang Nomor 7 Tahun 2014 berbunyi:Kebijakan perdagangan Luar Negeri meliputi pengharmonisasian standard dan prosedur kegiatan perdagangan dengan mitra dagang. ${ }^{42}$

\section{Penutup}

Berdasarkan pembahasan permasalahan di atas dapat ditarik kesimpulan yaitu bahwa Undang-Undang Nomor 7 Tahun 1994 Tentang Pengesahan Agreement Establishing The World Trade Organization (Persetujuan Pembentukan Organisasi Perdagangan Dunia) terdapat isi atau materi yang memuat pengaturan prinsip GATT/WTO, yakni pada huruf A, B, dan C. Penjelasan atas Undang-Undang Nomor 7 Tahun 1994 Tentang Pengesahan Agreement Establishing The World Trade Organization (Persetujuan Pembentukan Organisasi Perdagangan Dunia), General Agreement on Tariffs and Trade/GATT (Persetujuan Umum mengenai Tarif dan Perdagangan) merupakan perjanjian perdagangan multilateral dengan tujuan menciptakan perdagangan bebas, adil, dan membantu menciptakan pertumbuhan ekonomi dan pembangunan.

Selain itu, dalam Undang-Undang Nomor 7 Tahun 2014 Tentang Perdagangan terdapat beberapa prinsip-prinsip hukum dalam pengaturan perdagangan internasional. Namun ada pula prinsip hukum dalam pengaturan perdagangan internasional yang tidak terdapat kesesuaian dengan Undang-

${ }^{42}$ Lihat Undang-Undang Nomor 7 Tahun 2014 Tentang Perdagangan 
Undang Nomor 7 Tahun 2014 Tentang Perdagangan yakni prinsip persaingan bebas (Asymmetric Economic Conditions, Empowering, Free Competition) dengan Pasal 22 ayat (1), (2), dan (3).

\section{Referensi}

\section{Peraturan Perundang-Undangan/Konvensi}

Republik Indonesia. Undang-Undang Dasar 1945 . Undang-Undang Tentang Perdagangan. Undang-Undang Nomor 7 Tahun 2014. Lembar Negara Republik Indonesia Tahun 2014 Nomor 45. Tambahan Lembaran Negara Republik Indonesia Nomor 5512. . Undang-Undang Tentang Pengesahan Agreement Establishing The World Trade Organization (Persetujuan Pembentukan OrganisasiPerdagangan Dunia). Undang-Undang Nomor 7 Tahun 1994.

Undang-Undang Tentang Perjanjian Internasional. Undang-Undang Nomor 24 Tahun 2000. Lembar Negara Republik Indonesia Tahun 2000 Nomor 185. Agreement Establishing The World Trade Organization. The General Agreement on Tarrifs and Trade (GATT 1947). Vienna Convention on the Law of Treaties (1969).

\section{Buku}

Adolf, Huala. Hukum Ekonomi Internasional, Cet. Ketiga, PT Raja Grafindo Persada, Jakarta, 2003. Hukum Perdagangan Internasional, PT Raja Grafindo Persada, 2006.

. Hukum Perdagangan Internasional, Cet. Keenam, PT Raja Grafindo Persada, Jakarta, 2014. Black, Henry Campbell. Black's Law Dictionary, Edisis Revisi keempat, St. Paul, Minn: West Publishing Co, 1968.

Daud, Abu Busroh. Ilmu Negara, Cet. Kesembilan, Sinar Grafika Offset, Jakarta, 2013. 
Dirdjosisworo, Soedjono. Pengantar Hukum Dagang Internasional dalam, Cet. Pertama, PT Refika Aditama, Bandung, 2006.

Hata. Perdagangan Internasional dalam Sistem GATT dan WTO,

Cet. Pertama, PT Refika Aditama, Bandung, 2006.

Kusumaatmadja, Mochtar dan Etty R. Agoes, Pengantar Hukum

Internasional, Cet. kedua, P.T. Alumni, Jakarta, 2018.

Marzuki, Peter Mahmud. Penelitian Hukum. Cetakan ke-13.

Kharisma Putra Utama, Jakarta, 2017.

Parthiana, I Wayan. Hukum Perjanjian Internasional. Cetakan kesatu. CV. Mandar Maju, Bandung, 2018.

Putra, Ida Bagus dan Dharmawan Ni Ketut Supasti. Hukum

Perdagangan Internasional. Cetakan kesatu. Refika

Aditama, Bandung, 2017.

Suherman, Ade Maman. HukumPerdagangan Internasional, Cet. Pertama, Sinar Grafika Offset, Jakarta, 2014.

\section{Jurnal/Artikel/Karya Ilmiah}

Anggraeni, Nita. "Negara Berkembang Perlindungan Produk Dalam Negeri Dalam Konteks Hukum Perdagangan Internasional World Trade Organization (WTO)," Jurnal UIN Banten, 2017.

Budoyo, Sapto. "Konsep Langkah Sistemik Harmonisasi Hukum dalam Pembentukan Peraturan perundang-Undangan." Jurnal Ilmiah CIVIS,Vol. 4, No. 2 Juli 2014.

Butho, Zulfikar Ali. "Ratifikasi WTO Dan Dampaknya Pada Pembangunan Dan Pembaharuan Hukum Ekonomi Indonesia (Suatu Tinjauan Ontologis)," Jurnal Advokat, 2017.

Hendi Pia Chandra "Harmonisasi Pengaturan Anti Dumping Antara GATT Dengan CEPT-AFTA Dan Implementasinya Dalam Pengaturan Anti Dumping Di Indonesia ", Skripsi Sarjana Hukum, Fakultas Hukum Universitas Jambi, Jambi, 2017.

Hidayatullah, Syukri. "Perbandingan Hukum Pengaturan Standardisasi Menurut Agreement TBT dan UndangUndang No. 7 Tahun 2014 Tentang Perdagangan," Arena Hukum Vol. 9 No. 2 Agustus 2016. 
Hippy, Karmila "Praktik Ratifikasi Perjanjian Internasional di Indonesia," Jurnal Lex Administratum,Vol. 1, No. 2, April - Juni 2013.

Kadarukmi, M. E. Retno. "Dampak Implementasi GATT/WTO Terhadap Ekspor Impor Indonesia," Jurnal Administrasi Bisnis Vol. 9, No. 1, 2013.

Korah, Revy S. M.. "Prinsip-Prinsip Eksistensi General Agreement On Tariffs And Trade (GATT) Dan World Trade Organization (WTO) Dalam Era Pasar Bebas," Jurnal Hukum UNSRAT Vol. 22, No. 7 Agustus 2016.

Mukti, Takdir Ali. "Sistem Pasca Westphalia,Interaksi Transnasional dan Paradiplomacy," Journal Hubungan Internasional, Vol. 2, No. 2 Oktober 2013.

Musjtari, Dewi Nurul. "Dampak Liberalisasi Perdagangan Dalam WTO Agreement Terhadap Ketahanan Pangan Indonesia," Kanun Jurnal Ilmu Hukum No. 63 Agustus 2014.

Parthiana, I Wayan. "Kajian Akademis (Teoritis dan Praktis) atas Undang-Undang Nomor 24 Tahun 2000 Tentang Perjanjian Internasional Berdasarkan Hukum Perjanjian Internasiona," Jurnal Hukum Internasional, Vol. 5, No. 3, April 2008. "Beberapa

Pengimplementasian Kewajiban Negara Indonesia di Bawah Perjanjian Internasional,"Jurnal Hukum Internasional,Vol. 3, No. 1, 2017.

Pebrianto, Dony Yusra. "Implikasi Most Favoured Nation Terhadap Pengaturan Tarif Impor Di Indonesia," Journal Equitable Vol. 2, No. 1, 2018.

Prasudhi, Imawan Dicky. "Penanganan Sengketa Perdagangan Internasional Melalui WTO (World Trade Organization)," Jurnal Hukum Dan Dinamka Masyarakat Vol. 5, No. 12007.

Putra, Akbar Kurnia. "Agreement on Agriculture dalam World Trade Organization," Jurnal Hukum dan Pembangunan, Vol. 46, No. 1, 5 Maret 2016.

Rahadiyan, Inda. "Pemaknaan Dan Penerapan Prinsip Resiprositas Berdasarkan ASEAN Banking Integration 
Framework," Jurnal Hukum Ius Quia Iustum Faculty Of Law Vol. 26, 2019.

Riyanto, Sigit. "Kedaulatan Negara Dalam Kerangka Hukum Internasional Kontemporer," Yustisia Jurnal Hukum Vol. 1, No. 3, 2012.

Rudi. "Mencari Bentuk Kedaulatan Dalam UUD Tahun 1945," Fiat Justicia Jurnal Ilmu Hukum Vol. 7, 2013.

S, Revy M. Korah. "Prinsip-Prinsip Eksistensi General Agreement On Tariffs And Trade (GATT) Dan World Trade Organization (WTO) Dalam Era Pasar Bebas," Jurnal Hukum UNSRAT Vol. 22, No. 7 Agustus, 2016.

Sawy, Jessi Garfield. "Dampak Persetujuan World Trade Organization Terhadap Kebijakan Investasi dan Perdagangan (Studi Kasus: Keberatan Anggota WTO Terhadap Undang-Undang Mineral dan Batu Bara No. 4/2009)," Kanun Jurnal Ilmu Hukum Vol. 2, No. 1, 2018.

Sumartini, Siti. "Paham Kedaulatan Negara Ditinjau Dari Sifat Universalitas Hukum Internasional," Yustitia Vol. 5, No. 1, 2019.

Suwardi, Sri Setianingsih. "Beberapa Catatan Tentang UndangUndang Perjanjian Internasional,"Jurnal Hukum dan Pembangunan, 2017.

Wagiman. "Nilai, Asas, Norma dan Fakta Hukum: Upaya Menjelaskan dan Menjernihkan Pemahamannya," Jurnal Filsafat Hukum, Vol. 1, No. 1, Jakarta: Universitas 17 Agustus 1945, 2016.

Yanti, A. A. Istri Eka Krisna. "Prinsip Non Diskriminasi Tenaga

Kerja Asing Dalam Kerangka GATS," Jurnal Magister Hukum Udayana Vol. 7, No. 2 Juli, 2018.

Zaini, Zulfi Diane. "Implementasi Pendekatan Yuridis Normatif dan Pendekatan Normatif Sosiologis dalam Penelitian Ilmu Hukum," Pranata Hukum Vol. 6, No.2, Edisi 2011.

\section{Website}

http://evitays.blogspot.com/2017/05/uu-no-7-tahun-2014tentang-perdagangan.html?m=1. Diakses pada tanggal 10 Februari 2020, Pukul 22:37 WIB. 
https://www.google.com/amp/s/gunawansriguntoro.wordpr ess.com/2012/01/03/teori-teori-hukum/amp/. Diakses pada tanggal 13 Februari 2020, Pukul 07:38 WIB.

https://www.jogloabang.com/pustaka/uu-7-2014-

perdagangan. Diakses pada tanggal 10 Februari 2020, Pukul 22:17 WIB.

https://id.m.wikipwdia.org/wiki/Transnasionalisme. Diakses pada tanggal 15 Agustus 2020, Pukul 17:18 WIB. 